\title{
Chemical Composition and Bioactivity of Essential Oil of Ageratina adenophora from Bhaktapur District of Nepal
}

\author{
Bimala Subba* and Ram Chandra Kandel \\ Central Department of Chemistry, Tribhuvan University, Kirtipur, Kathmandu, Nepal \\ E-mail: bimalasubba@gmail.com
}

\begin{abstract}
The essential oil of Ageratina adenophora locally call Banmara was analyzed by GC-MS. A total of 45 volatile compounds was identified and torreyol (16.8\%) was the major component in oil. The sesquiterpene fraction was higher than the monoterpene one. The essential oil showed significant antibacterial activity against both gram positive (Klebsiella pneumoniae and Staphylococcus aureus) and gram negative (Escherichia coli and Proteus vulgaris) bacteria.
\end{abstract}

Key words: Ageratina adenophora, Banmara, essential oil, physiochemical parameters, Eupatorium adenophorum, antibacterial activity and Zone of Inhibition

\section{Introduction}

Eupatorium adenophorum (syn. Ageratina adenophora, common name: Crofton weed; Sticky snakeroot), a native of Mexico has naturalized in many countries ${ }^{1}$. A. adenophora belongs to the Asteraceae family. It is a perennial herb, nearly 1 meter hight, and erect, found in open and deforested areas of the central and eastern Nepal at altitude of 500-2000 m. It is a problem weed in forest plantations as it infests disturbed areas and prevents self-seeding of cultivated trees, and hence it is known as banmara in Nepal (killer of the forests) ${ }^{2,3}$. It grows as weed on vast expanses in many parts of the world and are an attractive source of bioactive natural products ${ }^{4,5,6}$. Various species of Eupatorium have been used in the traditional system of medicine in different parts of the world. The leaf juice of A. adenophora is used to stop bleeding of cut and wounds, forming $\operatorname{clots}^{7}$. Root juice is prescribed to treat fever. Pure juice of the leaf is poured in the eye to treat insomnia. A decoction of the plant has been recommended to treat jaundice and ulcers ${ }^{4}$.

Extensive work on the chemical constituents as well as on the composition of the essential oils of Argentina is reported in literatures. A. adenophora has been reported for its allelopathic effect ${ }^{8}$. A hepatotoxic compound (9-oxo-10, 11-dehydroagerophonrone) was identified from the crude extract of $A$. adenophora, this component promotes a chronic equine respiratory disease known as "Numinbah horse"and liver lesions ${ }^{9}$. They also found b-farnesene, germacrene D, bisabolene, caryophyllene and four more cadinene derivatives were also reported. Other compounds identified from the stems and leaves of this species were found to be 9-oxo-ageraphorone, 9- $\beta$-hydroxy-ageraphorone, epifriefdelinol, stigmasterol, octacosanoic acid, b-daucos-terol, $o$-hydroxycinnamic acid, ferulic acid, cafeicacid and 2isopropenyl-5-acetyl-6-hydroxybenzo-furan acetate.There are some previous reports on the antimicrobial activity of the oils of some species of Eupatorium ${ }^{10,11,12}$. However, the natural products profile and consequently the bioactivity is known to vary with the climate and geographic location of the plants ${ }^{13}$. The essential oils of Ageratina adenophora (syn: Eupatorium. adenophorum (Spreng.) King and H.E. Robins) of Nepal has not been investigated so far.

\section{${ }^{*}$ Corresponding author}


Thus, the paper presents the chemical composition, physicochemical properties and antibacterial activity of the essential oil extract from aerial part of A. adenophorum sample collected from Bhaktapur District, Nepal

\section{Materials and Methods}

\section{Plant Material}

About $2 \mathrm{~kg}$ plant material (aerial part) was collected from the Nagarkot VDC of Bhaktapur District, Nepal in February 2011. The plant was identified as Ageratina adenophora by using different taxonomic literatures ${ }^{14,15}$.

\section{Extraction of essential oil}

The powdered material of aerial part of plant (100 gm) together with water (5-10 times) was taken in volumetric flask and was hyro-distilled for 6 hour using a Clevenger apparatus ${ }^{16}$. This process was repeated several times. The separated oil was dried over anhydrous sodium sulphate (SigmaAldrich,USA). Samples were stored in a refrigerator $\left(4^{\circ} \mathrm{C}\right)$ until used.

\section{Analytical condition for GC/MS}

Analytical GC was recorded on gas chromatograph with a flame ionization detector using a capillary $30 \mathrm{~m}$ DB-5 column ( $\mathrm{J}$ and $\mathrm{W}$ Scientific, USA) with $0.25 \mathrm{~mm}$ i.d. and $0.1 \mathrm{~mm}$ film thickness. The temperature program was $50^{\circ} \mathrm{C}$ for 2 minute and increased at $10^{\circ} \mathrm{C} /$ minute up to $300^{\circ} \mathrm{C}$ for 3 minute. The carrier gas was Helium at a flow rate $1 \mathrm{ml} / \mathrm{min}$. MS was operated in the electron impact mode with ionization energy of $70 \mathrm{eV}$ on a JEOL AX505 mass spectrometer connected to HP-9000 computer system. Most constituents were identified by comparison of their GC retention indices with those of authentic standards available in the author's laboratory or with GC data previously published ${ }^{17,18,19}$. Identification was confirmed when possible by comparison of their mass spectra with those stored in the MS database (NIST,Wiley libraries) and with mass spectra literature data ${ }^{17,18,19}$. Relative amounts of detected compounds were calculated based on GC peak areas.

\section{Determination of physical parameters}

Physical parameters were determined according to the method of Guenther ${ }^{20}$.

\section{Specific gravity}

An ignition tube previously cleaned and dried was weighed and its weight was determined to be W. The tube was filled with the oil and was weighed as ' $\mathrm{W}_{1}$ '. The same procedure was performed using the same tube containing water and its weight was noted as ' $\mathrm{W}_{2}$ '. Then specific gravity was calculated using the formula,

$$
\mathrm{d}_{\mathrm{t}}=\frac{w_{1}-w}{w_{2}-w}
$$

\section{Refractive index}

The refractive index of the oil was measured by using Abbe's refractometer.

\section{Optical rotation}

Different concentration of oil solutions $(1.0 \%, 0.5 \%, 0.25 \%)$ were prepared in methanol and the optical rotation was measured for the solutions of different concentrations. Then the specific rotation was calculated using the formula. 


$$
[\alpha]^{t}{ }_{D}=\frac{\alpha}{l \times c}
$$

Where, ' $\alpha$ ' is the angle of rotation of the plane of plane polarized Light, ' 1 ' is the length of polarimeter tube (mm), 'c' is the concentration of oil solution and ' $\mathrm{t}$ ' is the temperature at the time of measurement.

\section{Determination of chemical parameter}

\section{Saponification value}

Saponification value was determined by standard procedure. Ageratina essential oil $(0.5 \mathrm{gm})$ was accurately weighed in a $250 \mathrm{~mL}$ conical flask and dissolved in $10 \mathrm{~mL}$ of ethanol and $2.5 \mathrm{~N}$ potassium hydroxide $(\mathrm{KOH})$ solution was added. This procedure was performed in duplicate and blank experiment was also performed omitting the oil. The mixture was refluxed for two hours then cooled. The unreacted $\mathrm{KOH}$ was titrated with standard N/2 oxalic acid by adding 2-3 drops of phenolphthalein indicator. Then, the saponification value was determined using the following equation,

Saponification value $=\frac{56 \times\left(\mathrm{V}_{1}-\mathrm{V}_{2}\right) \mathrm{X}}{2 \times 1000 \mathrm{X}}$

Where, ' $\mathrm{W}$ ' is the weight of oil, ' $\mathrm{V}_{1}$ ' is the volume of $\mathrm{N} / 2$ oxalic acid for blank and ' $\mathrm{V}_{2}$ ' is the volume of $\mathrm{N} / 2$ oxalic acid for sample

\section{Acid value}

Acid value was determined according to the method of Guenther ${ }^{20}$. Oil (0.5 gm) was accurately weighted into a $250 \mathrm{~mL}$ conical flask and dissolved in $10 \mathrm{~mL}$ of neutral $95 \%$ ethanol and 2-3 drops of phenolphthalein indicator was added. The free acid was then titrated with standard $0.1 \mathrm{~N}$ aqueous sodium hydroxide solution by adding the alkali drop-wise at a uniform rate of about 30 drops per minute. The content of the flask was continuously agitated. The first appearance of the red coloration that did not fade within 10 seconds was considered the end point. Then, the acid value (A.V) was calculated using the following equation,

$$
\text { A.V. }=\frac{5.61(\text { Number of } \mathrm{mL} \text { of } 0.1 \mathrm{~N} \mathrm{NaOH})}{\text { Weight of sample in gram }}
$$

\section{Iodine number}

Iodine number was determined according to the method of Guenther ${ }^{20}$. Oil $(0.25 \mathrm{gm})$ was dissolved in $10 \mathrm{~mL}$ of chloroform. Then $25 \mathrm{~mL}$ of iodobromide solution was added and allowed to stand for 30 minutes in dark. Again $30 \mathrm{~mL}$ of $1 \mathrm{~N}$ potassium iodide and $100 \mathrm{~mL}$ of distilled water were added and the liberated iodine was titrated with N/10 solution of sodium thiosulphate with constant shaking. When iodine color became quite pale, $1 \mathrm{~mL}$ of $1 \%$ starch solution was added and the titration was continued until the blue color was discharged. A blank test was also carried out parallel under identical condition. The iodine number was determined using the formula,

Iodine number $=\frac{1.269\left(\mathrm{~V}_{1}-\mathrm{V}_{2}\right)}{\mathrm{W}}$ 
Where, ' $\mathrm{W}$ ' is the weight of sample, ' $\mathrm{V}_{1}$ ' is the number of $\mathrm{mL}$ of sodium thiosulphate consumed by the blank, ' $\mathrm{V}_{2}$ ' is the number of $\mathrm{mL}$ of sodium thiosulphate consumed by the test sample.

Iodobromide solution was prepared by dissolving iodine $(13.2 \mathrm{gm})$ in $1000 \mathrm{~mL}$ glacial acetic acid by gentle heating. The solution was cooled to $25^{\circ} \mathrm{C}$ and the iodine content in $20 \mathrm{~mL}$ was determined by titration with N/10 Sodium thiosulphate. To the remaining of the solution a quantity of bromine molecularly equivalent to that of the iodine present was added.

\section{Antibacterial Screening}

Inhibition of bacterial growth was tested by using the paper disc diffusion method with slight modification $^{21}$.

\section{Micro organism}

The micro organisms used in this study were identified strains obtained from Central Department of Microbiology, T.U. Among bacteria taken in this study, two were gram positive and two were gram negative as given below.

\section{Gram positive bacteria: Klebsiella pneumoniae and Staphylococcus aureus}

Gram negative bacteria: Escherichia coli and Proteus vulgaris

\section{Antimicrobial activity}

The anti microbial activity of the essential oil was carried by disc diffusion method ${ }^{21}$. A suspension of tested micro organisms was spread on Muller-Histon Agar (MHA) medium. The sterile filter paper discs $(6 \mathrm{~mm}$ in diameter) were individually impregnated with different concentration of oil prepared in ethanol and then placed into the agar plates which had previously been inoculated with the tested micro organisms. The plates were subsequently incubated overnight at $37^{\circ} \mathrm{C}$. After incubation the growth inhibition rings were quantified by measuring the diameter of the zone of inhibition in $\mathrm{mm}$. For control petroleum ether discs were used. All tests were performed in triplicate.

\section{Results and Discussion}

The essential oil obtained by hydrodistillation of the aerial part of A. adenophora was slightly viscous, whitish in color and with characteristic odor. The yield of the oil was $4.5 \%$ on the fresh weight basis. Gas chromatophraphy analysis of the essential oil showed the presence 45 components and the major compound was found to be torreyol (16.8\%). Other representative components of the oil were identified as 2-pentanone (7.71\%), germacrene (7.49\%), bornyl acetate $(7.51 \%), 1-\alpha$-bisabolene $(6.82 \%)$, $\delta$-cadinene $(6.4 \%), \alpha$-bisabolol $(5.1 \%)$. The complete list of identified compounds of the oil, their retention time and percentage composition are given in Table 1 . The earlier investigation of the essential oil of E. adenophorum leaves from India shows 1-napthalenol (17.50\%), $\alpha$-bisabolol (9.53\%), bornyl acetate $(8.98 \%), \beta$-bisabolene $(6.16 \%)$, germacrene-D $(5.74 \%), \alpha$-phellandrene $(3.85 \%)$ and a di-epi- $\alpha$ cedrene $(2.98 \%)^{12}$. Weyerstahl and co-workers from India (1997) reported the composition of the essential oil of flowers of E. adenophorum ${ }^{22}$. The major constituents were $\alpha$-phellandrene $(15.3 \%)$, camphene $(12.2 \%)$, bornyl acetate $(10.6 \%), p$-cymene $(8.5 \%), \gamma$-curcumene $(4.5 \%)$ and 2 -carene. PalaPaul and coworkers (2010) reported the analysis of the essential oil of the aerial parts of A. adenophora ${ }^{24}$. The major constituents were $p$-cymene (11.6\%), $\alpha$-phellandrene $(5.7 \%), \gamma$-curcumene $(5.0 \%), \delta$-2-carene $(5.0 \%)$, camphene $(4.8 \%)$, and endo-bornyl acetate $(4.4 \%)^{23}$. The composition of the essential oil from the aerial part of A. adenophora obtained here is supported by similar previous reports on this species from different countries. They reported the oils of Ageratina (= Eupatorium) are richer in sesquiterpenes than in monoterpene compounds. However, there is remarkable difference in the nature and relative 
content of different constituents in the previous reports by Papa-paul et al 2010 and the data on Table 1. The sample used in this study and those in the previous studies might be representing different chemotypes.

Table 1. Percentage Composition of Essential oil from the aerial parts of A. adenophora

\begin{tabular}{|c|c|c|c|}
\hline SN & Compounds & $\begin{array}{l}\text { Retention } \\
\text { Time }\end{array}$ & $\begin{array}{c}\text { Area } \\
\%\end{array}$ \\
\hline 1 & 2-Pentanone, 4-hydroxy-4-methyl- (CAS) Diacetone alcohol & 5.733 & 7.71 \\
\hline 2 & $\begin{array}{l}\text { Bicyclo[2.2.1]heptane, 2,2-dimethyl-3-methylene- (CAS) 3,3- } \\
\text { Dimethyl-2-methylenenorbornane }\end{array}$ & 8.058 & 0.4 \\
\hline 3 & $p$-Mentha-1,4(8)-diene & 9.183 & 0.73 \\
\hline 4 & $\begin{array}{l}\text { 1,3-Cyclohexadiene, 2-methyl-5-(1-methylethyl)- (CAS) p- } \\
\text { Mentha-1,5-diene }\end{array}$ & 9.267 & 1.05 \\
\hline 5 & Benzene, methyl(1-methylethyl)- (CAS) Cymol & 9.717 & 1.96 \\
\hline 6 & $\beta$-Linalool & 11.325 & 0.22 \\
\hline 7 & endo-2-Hydroxy-1,7,7-trimethylnorbornane & 12.892 & 0.53 \\
\hline 8 & $p$-Mentha-1,5-dien-8-ol & 13.417 & 0.24 \\
\hline 9 & Bornyl acetic ether & 15.325 & 7.51 \\
\hline 10 & Camphene & 16.842 & 0.42 \\
\hline 11 & $\begin{array}{l}\text { Bicyclo[2.2.1]heptane, 2,2-dimethyl-3-methylene- (CAS) 3,3- } \\
\text { Dimethyl-2-methylenenorbornane }\end{array}$ & 16.975 & 0.24 \\
\hline 12 & $\begin{array}{l}\text { Bicyclo[7.2.0]undec-4-ene, 4,11,11-trimethyl-8-methylene-, [1R- } \\
\left.\left(1 \mathrm{R}^{*}, 4 \mathrm{E}, 9 \mathrm{~S}^{*}\right)\right]\end{array}$ & 18 & 1.91 \\
\hline 13 & 2-Norpinene, 2,6-dimethyl-6-(4-methyl-3-pentenyl)- & 18.167 & 2.07 \\
\hline 14 & beta.-Sesquiphellandrene & 18.283 & 0.72 \\
\hline 15 & (6Z)-7,11-Dimethyl-3-methylene-1,6,10-dodecatrien & 18.433 & 3.39 \\
\hline
\end{tabular}


J. Nepal Chem. Soc., vol. 30, 2012

\begin{tabular}{|c|c|c|c|}
\hline 16 & $\begin{array}{l}\text { 1H-Benzocycloheptene, 2,4a,5,6,7,8-hexahydro-3,5,5,9- } \\
\text { tetramethyl-, (R)- }\end{array}$ & 18.933 & 1.64 \\
\hline 17 & $\delta$-Cadinene & 19.017 & 6.4 \\
\hline 18 & Germacrene D & 19.1 & 7.59 \\
\hline 19 & trans-Caryophyllene & 19.158 & 1.49 \\
\hline 20 & 1,2,3,4,5-Pentamethylcyclopentadiene & 19.383 & 1.42 \\
\hline 21 & $\beta$-Bisabolene & 19.442 & 6.81 \\
\hline 22 & Tricyclo[7.2.0.0(3,8)]undec-4-ene, 4,8,11,11-tetramethyl & 19.6 & 0.56 \\
\hline 23 & $\beta$-Sesquiphellandrene & 19.733 & 2.18 \\
\hline 24 & $\begin{array}{l}\text { Naphthalene, 1,2,3,5,6,8a-hexahydro-4,7-dimethyl-1-(1- } \\
\text { methylethyl)-, (1S-cis)- (CAS) (+)-.delta.-Cadinene }\end{array}$ & 19.783 & 0.43 \\
\hline 25 & 5-Isopropyl-2-methylbicyclo[3.1.0]hex-3-en & 19.833 & 0.65 \\
\hline 26 & (3E)-4,4-Dimethyl-3-(3-methyl-3-butenylidene)-2-m & 19.908 & 1.11 \\
\hline 27 & Cyclohexene, 4-(1,5-dimethyl-1,4-hexadienyl)-1-methyl- & 20.017 & 0.7 \\
\hline 28 & Androstan-17-one, 3-ethyl-3-hydroxy-, (5.alpha.) & 20.242 & 1.05 \\
\hline 29 & (6E)-3,7,11-Trimethyl-1,6,10-dodecatrien-3-ol & 20.333 & 0.33 \\
\hline 30 & Andrographolide & 20,508 & 0.65 \\
\hline 31 & (-)-Spathulenol & 20.817 & 0.98 \\
\hline 32 & Caryophyllene oxide & 20.942 & 0.94 \\
\hline 33 & $\alpha$-Cedrol & 21.258 & 0.47 \\
\hline 34 & Biphenylene, 1,2,3,6,7,8,8a,8b-octahydro-4,5-dimethyl & 21.517 & 20.79 \\
\hline 35 & Guaiol & 21.583 & 0.83 \\
\hline 36 & Torreyol & 21.725 & 16.8 \\
\hline 37 & Isoledene & 21.808 & 0.75 \\
\hline
\end{tabular}


J. Nepal Chem. Soc., vol. 30, 2012

\begin{tabular}{|c|c|c|c|}
\hline 38 & $\begin{array}{l}\text { Azulene, 1,2,3,4,5,6,7,8-octahydro-1,4-dimethyl-7-(1- } \\
\text { methylethylidene)-, (1S-cis)- (CAS) Guaiene }\end{array}$ & 22.067 & 0.98 \\
\hline 39 & $\alpha$-Bisabolol & 22.45 & 5.1 \\
\hline 40 & $\begin{array}{l}\text { 4,6,6-Trimethyl-2-(3-methylbuta-1,3-dienyl)-3- } \\
\text { oxatricyclo[5.1.0.0(2,4)]octane }\end{array}$ & 22.633 & 1.11 \\
\hline 41 & 9H-Cycloisolongifolene, 8-oxo & 22.75 & 4.8 \\
\hline 42 & $\begin{array}{l}\text { Cyclodecacyclotetradecene, 14,15-didehydro- } \\
1,4,5,8,9,10,11,12,13,16,17,18,19,20 \text {-tetradecahydro }\end{array}$ & 23.15 & 0.51 \\
\hline 43 & $\begin{array}{l}\text { Bicyclo[4.4.0]dec-5-ene, 1,5-dimethyl-3-hydroxy-8-(1- } \\
\text { methylene-2-hydroxyethyl-1) }\end{array}$ & 24.35 & 1.15 \\
\hline 44 & 1,4,4,7a-Tetramethyl-2,4,5,6,7,7a-hexahydro-1H-indene-1,7-diol & 26.367 & 0.36 \\
\hline 45 & Di-epi- $\alpha$-cedrene & 27.192 & 0.28 \\
\hline
\end{tabular}

The physicochemical property of the oil was evaluated using the standard procedure and the result is presented in Table 2. The oil is levorotatory. The low saponification and acid number value of essential oil indicated the presence of fewer amounts of fatty acids and free acids but high iodine value of the oil indicated the presence of more unsaturated compounds.

Table 2. Physicochemical properties of the essential oil of A. Adenophora

\begin{tabular}{|c|c|c|}
\hline Parameters & Values & \\
\hline Specific gravity & 0.947 & \\
\hline Specific rotation & -37.3 & \\
\hline Refractive index & 1.549 & \\
\hline $\begin{array}{l}\text { Saponification value } \\
\text { value }\end{array}$ & $6.3^{24.4}$ & Acid \\
\hline Iodine value & 152 & \\
\hline
\end{tabular}

Antibacterial activity of essential oils of A. adenophora is shown in Table 3. Essential oil showed antibacterial activity against all four organisms tested. In comparison between the gram-positive and gram-negative bacteria, gram- positive bacterial strains were more susceptible to the concentration of oil than gram- negative bacteria suggesting that plant extracts are more active against gram-positive bacteria. Among the bacteria, K. pneumonia has higher value of $14 \mathrm{~mm}$ and $P$. vulgaris has lower value of $10 \mathrm{~mm}$ 
in $1 \mathrm{mg} / \mathrm{ml}$ concentration but similar effect in both gram positive and gram negative bacteria at minimum concentrations of $0.25 \mathrm{mg} / \mathrm{mL}$ (Table 3). The present observation that essential oil of A. adenophora has antibacterial activity can be correlated with study done by Kurade et al. $2010^{12}$. Antibacterial effect of essential oils is, generally, less against gram-negative bacteria than gram-positive bacteria ${ }^{13}$. According to liteture survey, A. adenophora has not been used extensively for any purpose in Nepal. Therefore this plant may become a high risk posed invasive species in near future. Thus, here it is concluded that our finding will be supportive for using invasive alien species A. adonophara as an attractive source of bioactive natural products.

Table 3. Antimicrobial activity of Ageratina adenophora essential oil against different micro-organisms

\begin{tabular}{|l|c|c|c|c|}
\hline & \multicolumn{4}{|c|}{ Zone of inhibition (ZOI) in mm/mL } \\
\hline $\begin{array}{l}\text { Test } \\
\text { organisms }\end{array}$ & $0.25 \mathrm{mg} / \mathrm{mL}$ & $0.5 \mathrm{mg} / \mathrm{mL}$ & $0.75 \mathrm{mg} / \mathrm{mL}$ & $1 \mathrm{mg} / \mathrm{mL}$ \\
\hline E.coli & 8 & 8 & 10 & 12 \\
\hline K. pneumoniae & 8 & 8 & 9 & 14 \\
\hline P. vulgaris & 8 & 9 & 10 & 10 \\
\hline S. aureus & 8 & 8 & 10 & 12 \\
\hline
\end{tabular}

\section{References}

1. Hoshovsky, M. C. and Lichti, R. (2007). Ageratina adenophora. http://ucce.ucdavis.edu/ datastore/detailreport.cfm?usernumber=2\&surveynumber=1829)

2. Sharma, K. C. and Chhetri, G. K. K. (1977). Reports on studies on the biological control of Eupatorium adenophorum. Nepalese Journal of Agriculture, 12, 135-157.

3. Morris, M. J. (1989). Host specificity studies of a leaf spot fungus, Phaeoramularia sp., for the biological control of Crofton weed (Ageratina adenophora) in South Africa. Phytophylactica, 21, 281-283.

4. Sharma, O. P. Dawra, R. K. Kurade, N. P. and Sharma, P. D. (1998). A review of the toxicosis and biological properties of the genus Eupatorium. Nature Toxins, 6, 1-14.

5. Sharma, P. D. and Sharma, O. P. (1995). Natural products chemistry and biological properties of the Ageratum plant. Environmental Toxicology and Chemistry, 50, 213-232.

6. James, L.F. Panter, K. E. Gaffield, W. Molyneux, R. J. (2004). Biomedical applications of poisonous plant research. Journal of Agricultural and Food Chemistry, 52, 3211-3230.

7. Bhattarai, N. K. (1997). Traditional herbal medicines used to treat wounds and injuries. In: Nepal. Tropical Doctor, Suppl. I: 43-7.

8. Rajbanshi, S.S. and Inubushi, K. (1998). Chemical and biochemical changes during laboratory scale composting of allelopathic plant leaves (Eupatorium adenophorum and Lantana camara). Biology and Fertility of Soils, 26, 66-71.

9. Oelrichs, P. B. Calanasan, C. A MacLeod, J.K. Seawright,A. A. Ng, J. C. (1995). Isolation of a compound from Eupatorium adenophorum (Spreng.) [Ageratina adenophora (Spreng.)] causing hepatotoxicity in mice. Natural Toxins, 3, 350-354. 
10. Gupta, M. Mazumder. U.K. Chaudhuri, I. Chaudhuri, R.K. Bose, P. Bhattacharya, S. Manikandan, L. and Patra, S. (2002). Antimicrobial activity of Eupatorium ayapana. Fitoterapia. 73, 168-170.

11. Sasikumar, J. M. Doss, A. P. and Doss, A. (2005) Antibacterial activity of Eupatorium glandulosum leaves. Fitoterapia, 76, 240-243.

12. Kurade, N. P. Jaitak, V. Kaul, V. K. and Sharma, P. (2010). Chemical composition and antibacterial activity of essential oils of Lantana camara, atum Houstonianum and Eupatorium adenophorum Pharmaceutical Biology, 48, 539-544.

13. Burt, S. (2004). Essential oils: Their antibacterial properties and potential applications in foods - A review. International Journal of Food Microbiology, 94, 223-253.

14. Bulletin of the Department of Medicinal Plant No.3, Medicinal Plants of Nepal,His majestys government, Minister of forest and soil conservation, Department of plant rescources, Thapathali, Kathmadu, Nepal,193, pp. 35.

15. Ioshi, A. R. and Edington, J. M. (1990). The use of medicinal plants by two village communities in the central development region of Nepal. Economic Botany, 44, 71-83.

16. Mechkovski, A. and Akerele, C.O. (1992). Quality control methods for medicinal plant materials, WHO/PHARM/92.559. World Health Organization, Switzerland.

17. Adams, R.P. (1995). Identification of Essential Oils Components by Gas Chromatography-Mass Spectrometry. Allured Publishing ;1,Co., Illinois, IL.

18. Jennings, W. and Shibamoto, T. (1980). Qualitative Analysis of Flavor and Fragrance Volatiles by Capillary Gas Chromatography, Academic Press, New York.

19. Libbey, L.M. (1991). A Paradox data base for GC/MS data on Components of Essential Oils and Other Volatiles. Journal of Essential Oil Research, 3, 192-194.

20. Guenther, E. (1960). The Essential oils. D-van Nostrand Company, Princeton, New Jersey, New York, I, 237-306.

21. Bauer, A.W. Kirby, M.D.K. Sherris, J.C. and Turck, M. (1966) Antibiotic susceptibility testing by standard single disc diffusion method. American Journal of Clinical Pathology, 45,493- 496.

22. Weyerstahl, P. Marschall, H. Seelmann, I. Kaul, V. K. (1997). Constituents of the flower essential oil of Ageratina adenohpora (Spreng.) K.et R. from India. Flavour and Fragrance Journal, 12, 387-396.

23. Pala-Paul, J. Perez-Alonso, M.J. Velasco-Negueruela, A. and Sanz, J. (2002). Analysis by gas chromatography-mass spectrometry of the vola- tile components of Ageratina adenophora Spreng., growing in the Canary Islands. Journal of Chromatigraphy A 947, 327-331. 